\title{
The Effects of Fucoxanthin Dietary Inclusion on the Growth Performance, Antioxidant Metabolism and Meat Quality of Broilers
}

-Author(s)
Gumus R'
Urcar Gelen S"
Koseoglu S'II
Ozkanlar S'v
Ceylan ZG"
Imik H"I
I Sivas Cumhuriyet University, Faculty of
Veterinary Medicine, Department of Animal
Nutrition and Nutritional Disorders, Sivas,
Turkey.
" Ataturk University, Faculty of Veterinary
Medicine, Department of Food Hygiene
and Technology, Erzurum, Turkey.
III Ataturk University, Faculty of Veterinary
Medicine, Department of Animal Nutrition
and Nutritional Disorders, Erzurum, Turkey.
Iv Ataturk University, Faculty of Veterinary
Medicine, Department of Biochemistry,
Erzurum, Turkey.

\section{-Mail Address}

Corresponding author e-mail address Recep Gumus

Sivas Cumhuriyet University, Faculty of Veterinary Medicine, Department of Animal Nutrition and Nutritional Disorders, 58140, Sivas, Turkey.

Phone: +90 346219 1010-2597

Email: recepgumus58@hotmail.com

\section{- Keywords}

Antioxidant, broiler, fucoxanthin, meat quality, performance.

\section{ABSTRACT}

Fucoxanthin is a major carotenoid found in marine brown algae. This study investigated the impact of fucoxanthin on the growth performance, antioxidant metabolism and meat quality of broilers. Overall, 180 one-day-old male broiler chicks (Ross 308) were assigned to one control group (CONT) and 2 treatment groups (FUCO1 and FUCO2), with six replicates of 10 birds each. The CONT, FUCO1 and FUCO2 birds were fed a basal diet supplemented with 0, 100 and 200 $\mathrm{mg} / \mathrm{kg}$ of fucoxanthin, respectively. Average body weight gain (BWG), feed intake (FI) and feed conversion ratio (FCR) were similar among the groups. Fucoxanthin increased catalase (CAT) and superoxide dismutase (SOD) activities and glutathione $(\mathrm{GSH})$ levels $(p<0.01)$, and reduced malondialdehyde (MDA) levels $(p<0.01)$ in the liver, breast and drumstick tissues. The effects of fucoxanthin on drumstick yellowness $\left(b^{*}\right)$ on day 3 and water activity $\left(a_{w}\right)$ on day 5 and breast lightness $\left(L^{*}\right)$ on day $3 b^{*}$ values days 2 and 5 were limited and variable. While fucoxanthin showed antimicrobial effect against Staphylococcus spp. in the breast meat on days 5 and 6 of storage $(p<0.05)$, its effects at different time periods and against other microorganisms varied. In conclusion, fucoxanthin did not affect performance parameters, but had a significant impact on antioxidant metabolism, and showed a limited effect on the microbial quality of meat.

\section{INTRODUCTION}

Fucoxanthin is a major natural carotenoid found in the chloroplasts of marine brown algae (Phaeophyceae), and accounts for almost 10\% of the total carotenoid production in the world (Hosakawa et al., 2006; Matsuno, 2001). Fucoxanthin has several physiological effects, including proton donation and free-radical scavenging (Sasaki et al., 2008; Yan et al., 1999), and has anticarcinogenic (Kotake et al., 2005) and anti-inflammatory effects (Heo et al., 2010; Sasaki et al., 2008). In a previous study carried out with broilers, an oral daily dose of $10 \mathrm{mg}$ of fucoxanthin per bird for two weeks improved plasma antioxidant status and meat color but did not affect their performance parameters (Sasaki et al., 2010).

The amount of free radicals generated by oxidation, which is a natural process that occurs during metabolic activities, may increase excessively due to various stress factors (Surai, 2015). Oxidative stress causes major cell damage, which leads to animal health problems and reduced yields (Fang et al., 2002; Halıc et al., 2012). Antioxidants are needed to prevent the generation of free radicals and to allow their elimination from the body without any harm to the body (Gumus et al., 2017; Surai, 2015). The enzymes superoxide dismutase (SOD) and catalase (CAT) and glutathione (GSH) play a major role in the antioxidant defense system of the body, and natural feed additives 
Gumus R, Urcar Gelen S, Koseoglu S, Ozkanlar S, Ceylan ZG, Imik H
The Effects of Fucoxanthin Dietary Inclusion on the Growth Performance, Antioxidant Metabolism and Meat Quality of Broilers have a positive impact on this system (Gümüş \& Imik, 2016; Halıc et al., 2012). Antioxidant additives are also used in the food industry for the prevention of oxidation reactions such as oil rancidity color change, as well as of microbiological spoilage, and thereby, for the extension of the shelf life of food (Alimentarius, 2010). It has been shown that antioxidant vitamins positively affect both the quality and shelf life of meat (Imik et al., 2012a; Imik et al., 2012b).

There are only very few studies on the use of fucoxanthin as a feed additive in animal nutrition. In most of the published studies, fucoxanthin was applied postmortem and its effects on meat were investigated (Sasaki et al., 2008). This study investigated the dietary inclusion of different levels of fucoxanthin on the growth performance, antioxidant metabolism in the liver, breast and drumstick tissues, and the quality of breast and drumstick meat of broilers.

\section{MATERIALS AND METHODS}

\section{Birds, experimental design, and diet}

The research protocol of the current study was approved by the local Ethics Committee for Animal Experiments of the Sivas Cumhuriyet University (Approval number: 2016/71).

The experiment was conducted in the Research and Application Center of the Faculty of Veterinary Medicine, Atatürk University. A total of 180 one-dayold male Ross 308 broilers were divided into three treatments with six replicates of 10 birds each. The feeding period was divided in starter diets, fed from 1 to 21 days of age, and finisher diets, fed from 22 to 42 days of age (Table 1). The experimental diets were based on a standard commercial feed used as control (CONT group), which was supplemented with $100 \mathrm{mg} / \mathrm{kg}$ fucoxanthin (FUCO1 group) and $200 \mathrm{mg} /$ $\mathrm{kg}$ fucoxanthin (FUCO2 group). The birds were housed in 18 three-storey cages measuring $100 \times 55 \times 35 \mathrm{~cm}$. Feed and water were supplied ad libitum. The ambient temperature was gradually decreased from $33^{\circ} \mathrm{C}$ in first week to $22^{\circ} \mathrm{C}$ on day 14 and was then kept constant afterwards. The lighting program applied was a continuous $23 \mathrm{~h}$ light. Diets formulated and considered as control according to the recommendation of NRC (1994) (Table 1). The nutritional composition of the diets was determined according to the AOAC (2005).

\section{Feed additives}

Fucoxanthin was added as the commercial product ThinOgen ${ }^{\mathrm{TM}}$ (BBG Company, Algae Health Sciences, USA) derived from Laminaria japonica seaweed,
Table 1 - Ingredients and chemical composition of the basal diets, $\mathrm{g} / \mathrm{kg}$

\begin{tabular}{|c|c|c|}
\hline & $\begin{array}{c}\text { Starter } \\
\text { (1 to } 21 \mathrm{~d})\end{array}$ & $\begin{array}{c}\text { Finisher } \\
\text { (22 to } 42 \mathrm{~d})\end{array}$ \\
\hline \multicolumn{3}{|l|}{ Ingredients $\mathrm{g} / \mathrm{kg}$} \\
\hline Corn & 514.6 & 562.0 \\
\hline Soyabean meal (\%44) & 393.5 & 316.5 \\
\hline Soybean oil & 31.8 & 66.0 \\
\hline Dicalcium phosphate & 21.1 & 17.3 \\
\hline Wheat bran* & 15.0 & 15.0 \\
\hline Calcium carbonate & 9.6 & 8.6 \\
\hline Sodium bicarbonate & 2.8 & 2.7 \\
\hline Salt & 2.7 & 2.8 \\
\hline Vit-Min. Premix** & 5 & 5 \\
\hline DL-methionine & 2.4 & 2.6 \\
\hline L-lysine HCL & 0.8 & 0.6 \\
\hline L-threonine & 0.7 & 0.9 \\
\hline \multicolumn{3}{|l|}{ Calculated analysis } \\
\hline Metabolizable energy, MJ/kg & 12.22 & 13.40 \\
\hline Crude protein, \% & 22.21 & 19.21 \\
\hline Ether extract\% & 3.48 & 5.65 \\
\hline Crude fibre, \% & 2.8 & 2.65 \\
\hline Lysine, \% & 1.19 & 1.02 \\
\hline Methionine, \% & 0.57 & 0.52 \\
\hline Calcium, \% & 0.96 & 0.81 \\
\hline Phosphorous, \% & 0.64 & 0.56 \\
\hline
\end{tabular}

*The fucoxanthine was added in replacement of wheat bran.

* * Contents per kilogram: vitamin A, 3,600,000 U; vitamin D3, 800,000 U; vitamin E, $7200 \mathrm{U}$; vitamin K3, $800 \mathrm{mg}$; thiamine, $720 \mathrm{mg}$; riboflavin, $2640 \mathrm{mg}$; calcium pantothenate, $4000 \mathrm{mg}$; niacin, 12,000 mg; pyridoxine, $1200 \mathrm{mg}$; folic acid, $400 \mathrm{mg}$; vitamin B12, 6 mg; biotin, 40 mg; choline, 100,000 mg; Mn, 39680 mg; Fe, 20000 mg; Zn, $33880 \mathrm{mg}$; Cu, $4000 \mathrm{mg}$; l, $400 \mathrm{mg} ; \mathrm{Se}, 80 \mathrm{mg}$.

containing $5 \%$ fucoxanthin oil as tested by HPLC. The (ThinOgen ${ }^{\mathrm{TM}}$ ) was added to the diets of the FUCO1 and FUCO2 groups at 100 and 200 mg fucoxanthin/kg diet, respectively.

\section{Performance parameters}

Body weight (BW), body weight gain (BWG) and feed intake (FI) were measured at 3, 10, 17, 24, 31 and 42 days of age. Feed conversion ratio (FCR) was calculated as total FI (g) / total BWG (g). Mortality was recorded when it occurred.

\section{Biochemical analyses}

Ten randomly selected male broilers per group were fasted for $10 \mathrm{~h}$, and then sacrificed. Liver, breast and drumstick tissues were collected, homogenized, and frozen in liquid nitrogen at $-80^{\circ} \mathrm{C}$, and stored until biochemical analyses.

The activities of the enzymes SOD and CAT and the levels of GSH and MDA in the liver, breast and drumstick tissues were determined. To prepare the tissues homogenates, the liver, breast and drumstick tissues 
were ground in liquid nitrogen using a tissuelyser device (QIAGEN, Tissuelyser II, Germany) at frequency $1 / \mathrm{s}$ for 30 seconds. These tissue samples were then used for biochemical analyses. All biochemical measurements were carried out using commercial test kits (Cayman, USA) in ELISA reader (BioTek, $\mu$ Quant, USA). For SOD determination, $200 \mu \mathrm{L}$ of the diluted Radical Detector were added in the SOD standard wells and $10 \mu \mathrm{L}$ of the standard in the designated wells, after which 10 $\mu \mathrm{L}$ of the sample were added to wells. Reactions were initiated by adding $20 \mu \mathrm{L}$ diluted xanthine oxidase to all wells. The plate was placed on shaker and incubated for $30 \mathrm{~min}$ at room temperature. Measurements were made using a spectrophotometer at 440-460 $\mathrm{nm}$ absorbance. For CAT determination, $100 \mu \mathrm{L}$ assay buffer, $30 \mu \mathrm{L}$ methanol and $20 \mu \mathrm{L}$ samples were added to the standard wells, and $100 \mu \mathrm{L}$ diluted assay buffer, $30 \mu \mathrm{L}$ methanol and $20 \mu \mathrm{L}$ diluted catalase were added to positive control wells. The reaction was initiated by adding $20 \mu \mathrm{L}$ diluted hydrogen peroxide to all wells. The plate was placed on shaker and incubated for 20 min at room temperature. Measurements were made using a spectrophotometer at $540 \mathrm{~nm}$ absorbance. For GSH determination, $50 \mu \mathrm{L}$ of the samples were added to each sample well. The plate cover was removed and $150 \mu \mathrm{L}$ of freshly-prepared assay cocktail were added to both standard and sample wells. The plate cover was replaced and the plate was incubated for $20 \mathrm{~min}$ in the dark. Measurements were made using a spectrophotometer at 405-414 $\mathrm{nm}$ absorbance. For MDA determination, $100 \mu \mathrm{L}$ of the samples or malondialdehyde standard were added to each vial. Vials were boiled for one hour, placed on ice for 10 min and then centrifuged for $10 \mathrm{~min}$ at $1600 \mathrm{xg}$ at 4 ${ }^{\circ} \mathrm{C}$. Vials stabilized at room temperature for $30 \mathrm{~min}$. Measurements were made using a spectrophotometer at 530-550 $\mathrm{nm}$ absorbance.

\section{Determination of meat quality}

At the end of the experimental period (42 days), 10 birds per group were slaughtered after 10-h fasting. Birds were bled for $120 \mathrm{~s}$, manually plucked, and washed. Carcasses were stored at $+4 \pm 1{ }^{\circ} \mathrm{C}$ for $24 \mathrm{~h}$, when drumstick meat and breast meat were separated. The meat from the drumsticks and breast were placed on polyethylene plates, covered with stretch film, and stored at $4 \pm 1^{\circ} \mathrm{C}$ for $6 \mathrm{~d}$. Subsequently, the samples were analyzed on $d$ 1, 2, 3, 4, 5 and 6 for $\mathrm{pH}$, water activity $\left(\mathrm{a}_{\mathrm{w}}\right)$, and color [ $\mathrm{L}^{*}$ (lightness), $a *$ (redness), $\quad b *$ (yellowness)] and microbial counts [Enterobacteriaceae, total psychrotrophic aerobic bacteria (TPAB), total mesophilic aerobic bacteria
(TMAB), Staphylococcus spp., Lactobacillus spp. and Pseudomonas spp.]. Microbiological analyses of the samples preceded the other analyses.

Water activity values were measured using an Aqualab 4TE (USA) device. Meat samples were placed in the container of the device for the reading of the $a_{w}$ values.

The $\mathrm{pH}$ values of the samples were measured as described by Gökalp et al. (2001). Accordingly, 10 g-portions of the homogenized samples were weighed and $100 \mathrm{~mL}$ of distilled water were added. Samples were homogenized for 1 min using an Ultra-Turrax (IKA Werk $\mathrm{T}$ 25, Germany) homogenizer and the $\mathrm{pH}$ values were measured using a pH meter (WTW Inolab, Germany).

The color intensities $\left(L^{*}, a^{*}, b^{*}\right)$ of the cross-sectional areas of the drumstick and breast meat samples were determined using a Minolta colorimeter (CR-200, Minolta Co, Osaka, Japan). Color measurements were performed directly on the surface of muscle tissue, by removing the skin.

The microbiological analyses of the samples were performed in compliance with the method described by Baumgart et al. (1993). Accordingly, $25 \mathrm{~g}$ of the meat samples were homogenized in $225 \mathrm{~mL}$ of sterile Ringer's solution. Subsequently, serial dilutions of the homogenates were prepared. Inoculations were made using the spread plate technique. The TMAB count was determined on Plate Count Agar (PCA, Merck) incubated under aerobic conditions at $30 \pm 1^{\circ} \mathrm{C}$ for $72 \pm 1 \mathrm{~h}$. The TPAB count was also determined on Plate Count Agar (PCA, Merck), but incubated under aerobic conditions at $7 \pm 1^{\circ} \mathrm{C}$ for 10 days. For Enterobacteriaceae enumeration, $1 \mathrm{~mL}$ of the appropriate dilutions was seeded on Violet Red Bile Dextrose Agar (VRBDA, Merck), and incubated at 30 ${ }^{\circ} \mathrm{C}$ under anaerobic conditions for $2 \mathrm{~d}$. Staphylococcus spp. counts were determined on mannitol-salt agar (MSA) incubated under aerobic conditions at $30 \pm 1^{\circ} \mathrm{C}$ for $48 \pm 1$ h. Pseudomonas spp. counts were determined on Pseudomonas Agar (Oxoid CM 0559) supplemented with CFC supplement (Oxoid SR 0103) and incubated under aerobic conditions at $25 \pm 1^{\circ} \mathrm{C}$ for $48 \pm 1$ hours. Lactobacillus spp. counts were determined on MRS Agar (De Man Rogosa and Sharpe) (Oxoid CM 1153) incubated under anaerobic conditions at $37 \pm 1^{\circ} \mathrm{C}$ for $48 \pm 1 \mathrm{~h}$. Bacterial counts were expressed in log cfu g-1.

\section{Statistical Analysis}

The data obtained was analyzed using the SPSS 20 software (SPSS, 2011) using one-way analysis of variance (ANOVA) test. Differences among means 
were determined by Duncan's post-test. The data were expressed as mean \pm standard error of mean (SEM). Differences were considered with significant at $p<0.05$ and $p<0.01$.

\section{RESULTS}

Growth performance results (BW, BWG, FI and $F(R)$ are presented in Table 2. Significantly higher BW $(p<0.05)$ on days 10 and 17 and BWG between days
3-10 and11-17were obtained in the of the FUCO1 and FUCO2 birds compared with the CONT group. During other time periods, no differences were detected among treatments $(p>0.05)$. There was no effect of treatments on FI and FCR ( $p>0.05)$ (Table 2).

It was determined that, in the liver and breast tissues of FUCO1andFUCO2 groups, the activities of both antioxidant enzymes SOD and CAT $(p<0.01)$ and the levels of GSH significantly increased $(p<0.01)$, whilst the level of MDA decreased $(p<0.05)$ compared with

Table 2 - Effects of dietary fucoxanthin supplementation on the growth performance in broiler chickens

\begin{tabular}{|c|c|c|c|c|}
\hline \multirow{2}{*}{ Items } & \multicolumn{3}{|c|}{ Groups } & \multirow{2}{*}{$p$-value } \\
\hline & CONT & FUCO1 & FUCO2 & \\
\hline \multicolumn{5}{|l|}{ BW, g } \\
\hline $3 d$ & $73.71 \pm 0.11$ & $73.53 \pm 0.85$ & $73.90 \pm 0.38$ & ns \\
\hline $10 d$ & $261.87 \pm 2.35^{b}$ & $276.06 \pm 6.19^{a}$ & $281.67 \pm 0.88^{a}$ & * \\
\hline $17 d$ & $561.44 \pm 7.81^{b}$ & $618.16 \pm 18.48^{a}$ & $639.26 \pm 36.85^{a}$ & * \\
\hline $24 d$ & $1123.89 \pm 32.72$ & $1079.58 \pm 74.33$ & $1212.96 \pm 18.79$ & ns \\
\hline $31 d$ & $1658.76 \pm 21.08$ & $1581.03 \pm 57.62$ & $1638.94 \pm 56.50$ & ns \\
\hline $42 \mathrm{~d}$ & $2417.78 \pm 117.15$ & $2331.67 \pm 54.03$ & $2358.33 \pm 173.76$ & ns \\
\hline \multicolumn{5}{|l|}{ BWG, $g$} \\
\hline $3-10 d$ & $26.74 \pm 0.35^{b}$ & $29.04 \pm 0.76^{a}$ & $29.68 \pm 0.15^{a}$ & * \\
\hline $11-17 d$ & $42.80 \pm 0.10^{b}$ & $48.87 \pm 0.73^{a}$ & $51.09 \pm 3.16^{a}$ & * \\
\hline $18-24 d$ & $80.35 \pm 3.94$ & $65.92 \pm 9.56$ & $81.96 \pm 0.52$ & ns \\
\hline $25-31 d$ & $76.41 \pm 2.67$ & $71.64 \pm 13.03$ & $70.44 \pm 9.35$ & ns \\
\hline $32-42 d$ & $84.34 \pm 10.69$ & $83.40 \pm 8.99$ & $81.29 \pm 13.34$ & ns \\
\hline $3-42 d$ & $63.32 \pm 3.17$ & $61.05 \pm 1.45$ & $62.18 \pm 4.71$ & ns \\
\hline \multicolumn{5}{|l|}{$\mathrm{Fl}, \mathrm{g}$} \\
\hline $3-10 d$ & $40.48 \pm 2.14$ & $42.95 \pm 1.34$ & $44.29 \pm 0.00$ & ns \\
\hline $11-17 d$ & $89.05 \pm 5.24$ & $91.43 \pm 2.86$ & $93.61 \pm 0.68$ & ns \\
\hline $18-24 d$ & $164.80 \pm 11.26$ & $164.13 \pm 5.85$ & $174.50 \pm 1.20$ & ns \\
\hline $25-31 d$ & $139.87 \pm 2.73$ & $140.36 \pm 2.81$ & $134.57 \pm 2.70$ & ns \\
\hline $32-42 d$ & $135.15 \pm 5.5$ & $123.38 \pm 11.32$ & $121.41 \pm 5.84$ & ns \\
\hline $3-42 d$ & $113.87 \pm 5.03$ & $112.44 \pm 1.97$ & $113.68 \pm 1.16$ & ns \\
\hline \multicolumn{5}{|l|}{ FCR, g/g } \\
\hline $3-10 d$ & $1.52 \pm 0.08$ & $1.48 \pm 0.03$ & $1.49 \pm 0.01$ & ns \\
\hline $11-17 d$ & $2.08 \pm 0.09$ & $1.87 \pm 0.03$ & $1.85 \pm 0.12$ & ns \\
\hline $18-24 d$ & $2.07 \pm 0.21$ & $2.60 \pm 0.36$ & $2.13 \pm 0.03$ & ns \\
\hline $25-31 d$ & $1.84 \pm 0.09$ & $2.10 \pm 0.39$ & $2.21 \pm 0.03$ & ns \\
\hline $32-42 d$ & $1.66 \pm 0.24$ & $1.54 \pm 0.27$ & $1.52 \pm 0.12$ & ns \\
\hline $3-42 d$ & $1.81 \pm 0.15$ & $1.84 \pm 0.03$ & $1.83 \pm 0.06$ & ns \\
\hline
\end{tabular}

All values are given as mean \pm SEM, $(n=60) . a, b$ : Means in the same row with different superscripts differ $(*: p<0.05)$.

ns: not significant ( $p>0.05)$. BW: Body weight, BWG: Body weight gain, Fl; Feed intake, FCR; Feed conversion ratio.

CONT, basal diet; FUC01, basal diet+100 mg/kg diet of Fucoxanthin; FUCO2, basal diet+200 mg/kg diet of Fucoxanthin.

the CONT group (Table 3). In the drumstick tissue, CAT activity increased only in FUCO2, whilst SOD activity and GSH levels were significantly increased both in FUCO1and FUCO2 $(p<0.01)$ relative to the CONT group. Similarly, in the drumstick tissue, MDA levels were decreased in FUCO1 and FUCO2 groups $(p<0.01)$ relative to the CONT group (Table 3 ).

In the drumstick meat, the TMAB count was significantly lower on the $5^{\text {th }}$ day of storage in the FUCO1 and FUCO2 groups and on the $6^{\text {th }}$ day of storage only in the FUCO2 group $(p<0.05)$ relative to the CONT group (Table 4). Furthermore, Staphylococcus spp. counts were also significantly lower in the drumstick meat on the $5^{\text {th }}$ and $6^{\text {th }}$ days of storage both in FUCO1 and FUCO2 groups $(p<0.01)$ relative to the CONT group (Table 4). On the other hand, lower Pseudomonas spp. counts in the drumstick meat were determined on the $3^{\text {rd }}$ day of storage in groupFUCO1 and on the $6^{\text {th }}$ day 
Table 3 - Effects of dietary fucoxanthin supplementation on antioxidant metabolism in liver, breast and drumstick tissues of broiler chickens

\begin{tabular}{|c|c|c|c|c|}
\hline \multirow{2}{*}{ Items } & \multicolumn{3}{|c|}{ Groups } & \multirow{2}{*}{$p$-value } \\
\hline & CONT & FUCO1 & FUCO2 & \\
\hline \multicolumn{5}{|c|}{ CAT, nmol/min/g protein } \\
\hline Liver & $4725.92 \pm 155.23^{b}$ & $5792.78 \pm 115.68^{a}$ & $5474.15 \pm 237.37^{a}$ & ** \\
\hline Breast & $693.87 \pm 34.38^{b}$ & $1547.70 \pm 215.08^{a}$ & $1106.49 \pm 167.29^{a}$ & $* *$ \\
\hline Drumstick & $703.22 \pm 60.96^{b}$ & $1191.53 \pm 137.75^{\mathrm{ab}}$ & $1316.58 \pm 128.43^{a}$ & ** \\
\hline \multicolumn{5}{|c|}{ SOD, U/mg protein } \\
\hline Liver & $20.31 \pm 1.36^{b}$ & $26.32 \pm 4.32^{\mathrm{a}}$ & $27.50 \pm 0.84^{a}$ & $* \star$ \\
\hline Breast & $20.64 \pm 1.35^{b}$ & $31.55 \pm 1.69^{a}$ & $34.32 \pm 2.30^{a}$ & ** \\
\hline Drumstick & $27.22 \pm 2.01^{\mathrm{b}}$ & $40.15 \pm 3.19^{a}$ & $41.41 \pm 2.93^{\mathrm{a}}$ & ** \\
\hline \multicolumn{5}{|c|}{$\mathrm{GSH}, \mu \mathrm{mol} / \mathrm{g}$ protein } \\
\hline Liver & $24.19 \pm 2.64^{b}$ & $37.04 \pm 3.86^{a}$ & $36.71 \pm 4.23^{\mathrm{a}}$ & * \\
\hline Breast & $3.56 \pm 0.41^{b}$ & $8.80 \pm 0.62^{a}$ & $9.56 \pm 0.83^{a}$ & ** \\
\hline Drumstick & $12.18 \pm 1.34^{\mathrm{b}}$ & $26.93 \pm 2.24^{\mathrm{a}}$ & $28.05 \pm 2.52^{\mathrm{a}}$ & ** \\
\hline \multicolumn{5}{|c|}{ MDA, $\mu$ mol/g protein } \\
\hline Liver & $8.39 \pm 0.83^{a}$ & $5.72 \pm 0.50^{b}$ & $4.49 \pm 0.38^{b}$ & $\star *$ \\
\hline Breast & $2.73 \pm 0.98^{a}$ & $1.39 \pm 0.17^{b}$ & $1.56 \pm 0.30^{b}$ & $*$ \\
\hline Drumstick & $4.64 \pm 0.65^{a}$ & $2.45 \pm 0.34^{b}$ & $2.00 \pm 0.30^{b}$ & ** \\
\hline
\end{tabular}

All values are given as mean $\pm \mathrm{SEM},(n=10)$. a, b: Means in the same row with different superscripts differ $\left({ }^{*}: p<0.05\right),\left({ }^{* *}: p<0.01\right)$. ns: not significant $(p>0.05)$. CAT, catalase; SOD, superoxide dismutase; MDA, malondialdehyde; GSH, glutathione. CONT, basal diet; FUCO1, basal diet+100 mg/kg diet of Fucoxanthin; FUCO2, basal diet+200 mg/kg diet of Fucoxanthin.

Table 4 - Effects of dietary fucoxanthin supplementation and storage time on TMAB, Enterobacteriaceae, Lactobacillus spp., Staphylococcus spp., Pseudomonas spp. and TPAB counts in chicken drumstick meat (log cfu g-1)

\begin{tabular}{|c|c|c|c|c|c|c|c|}
\hline Days & Groups & $T M A B$ & Enterobacteriaceae & Lactobacillus spp. & Staphylococcus spp. & Pseudomonas spp. & TPAB \\
\hline \multirow[t]{4}{*}{1} & CONT & $4.76 \pm 0.02^{b}$ & $5.02 \pm 0.32$ & $5.48 \pm 0.34$ & $4.20 \pm 0.12$ & $4.16 \pm 0.12^{\mathrm{a}}$ & $2.69 \pm 0.09^{b}$ \\
\hline & FUCO1 & $4.51 \pm 0.01^{b}$ & $4.32 \pm 0.32$ & $4.75 \pm 0.18$ & $3.45 \pm 0.45$ & $3.35 \pm 0.05^{b}$ & $2.84 \pm 0.01^{b}$ \\
\hline & FUCO2 & $6.12 \pm 0.16^{a}$ & $4.94 \pm 0.10$ & $5.13 \pm 0.11$ & $3.92 \pm 0.08$ & $4.34 \pm 0.22^{\mathrm{a}}$ & $4.06 \pm 0.28^{a}$ \\
\hline & $p$-value & ** & ns & ns & ns & * & * \\
\hline \multirow[t]{4}{*}{2} & CONT & $6.02 \pm 0.54$ & $5.49 \pm 0.55$ & $5.34 \pm 0.26$ & $5.02 \pm 0.26$ & $4.88 \pm 0.16$ & $4.52 \pm 0.00$ \\
\hline & FUCO1 & $6.18 \pm 0.18$ & $5.37 \pm 0.01$ & $5.77 \pm 0.03$ & $4.25 \pm 0.21$ & $5.53 \pm 0.12$ & $4.90 \pm 0.04$ \\
\hline & FUCO2 & $6.65 \pm 0.03$ & $6.05 \pm 0.07$ & $5.55 \pm 0.23$ & $3.95 \pm 0.47$ & $5.73 \pm 0.28$ & $4.67 \pm 0.28$ \\
\hline & $p$-value & ns & ns & ns & ns & ns & ns \\
\hline \multirow[t]{4}{*}{3} & CONT & $5.18 \pm 0.18^{c}$ & $5.49 \pm 0.17$ & $5.11 \pm 0.11^{b}$ & $4.59 \pm 0.11$ & $6.08 \pm 0.00^{\mathrm{a}}$ & $6.18 \pm 0.06$ \\
\hline & FUCO1 & $6.28 \pm 0.19^{b}$ & $5.32 \pm 0.48$ & $6.54 \pm 0.06^{a}$ & $4.54 \pm 0.06$ & $5.61 \pm 0.10^{b}$ & $5.87 \pm 0.01$ \\
\hline & FUCO2 & $7.03 \pm 0.08^{\mathrm{a}}$ & $5.46 \pm 0.02$ & $5.40 \pm 0.10^{b}$ & $4.15 \pm 0.15$ & $6.21 \pm 0.13^{\mathrm{a}}$ & $6.32 \pm 0.32$ \\
\hline & $p$-value & ** & ns & ** & ns & * & ns \\
\hline \multirow[t]{4}{*}{4} & CONT & $6.99 \pm 0.12$ & $5.95 \pm 0.38$ & $6.90 \pm 0.00$ & $5.13 \pm 0.16$ & $6.61 \pm 0.01^{b}$ & $6.62 \pm 0.11$ \\
\hline & FUCO1 & $7.96 \pm 0.27$ & $5.63 \pm 0.93$ & $6.80 \pm 0.16$ & $5.26 \pm 0.08$ & $6.91 \pm 0.01^{\mathrm{a}}$ & $6.92 \pm 0.06$ \\
\hline & FUCO2 & $7.46 \pm 0.18$ & $5.76 \pm 0.02$ & $6.66 \pm 0.18$ & $4.39 \pm 0.27$ & $6.90 \pm 0.03^{a}$ & $5.66 \pm 0.70$ \\
\hline & $p$-value & ns & ns & ns & ns & * & ns \\
\hline \multirow[t]{4}{*}{5} & CONT & $7.88 \pm 0.01^{\mathrm{a}}$ & $6.95 \pm 0.39$ & $6.41 \pm 0.01$ & $5.93 \pm 0.30^{a}$ & $7.67 \pm 0.03$ & $7.48 \pm 0.18$ \\
\hline & FUCO1 & $7.45 \pm 0.15^{b}$ & $6.59 \pm 0.81$ & $6.44 \pm 0.48$ & $4.78 \pm 0.18^{b}$ & $7.79 \pm 0.09$ & $7.70 \pm 0.13$ \\
\hline & FUCO2 & $7.04 \pm 0.04^{c}$ & $5.20 \pm 0.60$ & $6.42 \pm 0.06$ & $4.46 \pm 0.02^{b}$ & $7.58 \pm 0.29$ & $7.32 \pm 0.24$ \\
\hline & $p$-value & * & ns & ns & * & ns & ns \\
\hline \multirow[t]{4}{*}{6} & CONT & $8.19 \pm 0.05^{a}$ & $7.16 \pm 0.06^{b}$ & $7.01 \pm 0.00$ & $6.35 \pm 0.20^{a}$ & $8.72 \pm 0.12^{\mathrm{a}}$ & $8.53 \pm 0.08$ \\
\hline & FUCO1 & $8.01 \pm 0.05^{a}$ & $7.71 \pm 0.10^{a}$ & $6.66 \pm 0.19$ & $4.69 \pm 0.09 c$ & $8.79 \pm 0.06^{a}$ & $8.48 \pm 0.03$ \\
\hline & FUCO2 & $7.70 \pm 0.00^{b}$ & $6.93 \pm 0.01^{b}$ & $6.73 \pm 0.15$ & $5.32 \pm 0.02^{b}$ & $8.23 \pm 0.06^{b}$ & $8.19 \pm 0.21$ \\
\hline & $p$-value & $\star \star$ & ** & ns & ** & * & ns \\
\hline
\end{tabular}

All values are given as mean $\pm \mathrm{SEM},(n=10)$. a-d: Means in the same column with different superscripts differ $\left({ }^{*}: p<0.05\right),\left({ }^{* *}: p<0.01\right) . n s:$ not significant $(p>0.05)$.

CONT, basal diet; FUCO1, basal diet+100 mg/kg diet of Fucoxanthin; FUCO2, basal diet+200 mg/kg diet of Fucoxanthin. TMAB; total mesophilic aerobic bacteria, TPAB; total psychrotrophic aerobic bacteria.

of storage in group FUCO2 $(p<0.05)$ of the FUCO1 and FUCO2 birds (Table 4). In the breast meat, a significant decrease in $T M A B$ counts was detected on the $5^{\text {th }}$ and $6^{\text {th }}$ days of storage and in the Enterobacteriaceae counts on the $6^{\text {th }}$ day of storage in group FUCO2 $(p<0.05)$ relative to the CONT group (Table 5). Staphylococcus 
Table 5 - Effects of dietary fucoxanthin supplementation and storage time on TMAB, Enterobacteriaceae, Lactobacillus spp., Staphylococcus spp., Pseudomonas spp. and TPAB counts in chicken breast meat (log cfu g-1)

\begin{tabular}{|c|c|c|c|c|c|c|c|}
\hline Days & Groups & $T M A B$ & Enterobacteriaceae & Lactobacillusspp. & Staphylococcusspp. & Pseudomonas spp. & TPAB \\
\hline \multirow[t]{4}{*}{1} & CONT & $4.42 \pm 0.03^{c}$ & $3.98 \pm 0.50$ & $4.89 \pm 0.01$ & $4.25 \pm 0.07$ & $4.26 \pm 0.22$ & $2.31 \pm 0.01$ \\
\hline & FUCO1 & $5.11 \pm 0.01^{b}$ & $4.39 \pm 0.39$ & $4.27 \pm 0.04$ & $4.08 \pm 0.04$ & $3.49 \pm 0.01$ & $3.02 \pm 0.02$ \\
\hline & FUCO2 & $5.37 \pm 0.03^{a}$ & $5.77 \pm 0.65$ & $5.40 \pm 0.88$ & $3.54 \pm 0.24$ & $3.30 \pm 0.30$ & $3.15 \pm 0.85$ \\
\hline & $p$-value & ** & ns & ns & ns & ns & ns \\
\hline \multirow[t]{4}{*}{2} & CONT & $6.24 \pm 0.44$ & $6.30 \pm 0.04$ & $5.94 \pm 0.71$ & $4.98 \pm 0.07^{a}$ & $4.06 \pm 0.02^{b}$ & $4.28 \pm 0.13$ \\
\hline & FUCO1 & $6.44 \pm 0.21$ & $4.86 \pm 0.26$ & $6.44 \pm 0.06$ & $3.95 \pm 0.49^{b}$ & $5.17 \pm 0.06^{a}$ & $4.60 \pm 0.36$ \\
\hline & FUCO2 & $5.72 \pm 0.24$ & $5.78 \pm 0.43$ & $5.53 \pm 0.10$ & $4.05 \pm 0.10^{b}$ & $5.25 \pm 0.05^{\mathrm{a}}$ & $4.55 \pm 0.40$ \\
\hline & $p$-value & ns & ns & ns & ** & ** & ns \\
\hline \multirow[t]{4}{*}{3} & CONT & $5.62 \pm 0.22$ & $5.35 \pm 0.03$ & $5.04 \pm 0.04^{b}$ & $4.15 \pm 0.15$ & $5.95 \pm 0.01^{b}$ & $5.94 \pm 0.01$ \\
\hline & FUCO1 & $6.54 \pm 0.24$ & $5.71 \pm 0.29$ & $6.20 \pm 0.12^{\mathrm{a}}$ & $4.53 \pm 0.01$ & $6.11 \pm 0.01^{\mathrm{a}}$ & $5.82 \pm 0.01$ \\
\hline & FUCO2 & $6.36 \pm 0.08$ & $5.04 \pm 0.44$ & $6.03 \pm 0.25^{\mathrm{a}}$ & $4.41 \pm 0.03$ & $6.07 \pm 0.04^{a}$ & $5.78 \pm 0.24$ \\
\hline & $p$-value & ns & ns & * & ns & * & ns \\
\hline \multirow[t]{4}{*}{4} & CONT & $6.60 \pm 0.30^{b}$ & $5.54 \pm 0.08^{b}$ & $5.72 \pm 0.12$ & $3.15 \pm 0.15^{b}$ & $6.57 \pm 0.12$ & $6.50 \pm 0.14$ \\
\hline & FUCO1 & $7.93 \pm 0.20^{\mathrm{a}}$ & $6.59 \pm 0.39^{a}$ & $5.78 \pm 0.78$ & $4.55 \pm 0.01^{\mathrm{a}}$ & $6.48 \pm 0.16$ & $6.86 \pm 0.34$ \\
\hline & FUCO2 & $7.49 \pm 0.06^{\mathrm{ab}}$ & $5.08 \pm 0.00^{b}$ & $7.17 \pm 0.06$ & $4.64 \pm 0.01^{\mathrm{a}}$ & $6.64 \pm 0.13$ & $6.69 \pm 0.24$ \\
\hline & $p$-value & * & * & ns & $\star *$ & ns & ns \\
\hline \multirow[t]{4}{*}{5} & CONT & $7.43 \pm 0.03^{a}$ & $6.97 \pm 0.41$ & $6.97 \pm 0.03$ & $5.68 \pm 0.01^{a}$ & $7.62 \pm 0.01$ & $7.50 \pm 0.10$ \\
\hline & FUCO1 & $7.45 \pm 0.15^{a}$ & $6.82 \pm 0.46$ & $5.40 \pm 0.50$ & $5.20 \pm 0.01^{c}$ & $7.54 \pm 0.22$ & $7.66 \pm 0.12$ \\
\hline & FUCO2 & $6.15 \pm 0.15^{b}$ & $5.04 \pm 0.74$ & $6.53 \pm 0.13$ & $5.29 \pm 0.01^{b}$ & $7.54 \pm 0.06$ & $7.68 \pm 0.00$ \\
\hline & $p$-value & $* *$ & ns & ns & ** & ns & ns \\
\hline \multirow[t]{4}{*}{6} & CONT & $7.94 \pm 0.09^{a}$ & $7.28 \pm 0.10^{b}$ & $6.62 \pm 0.20$ & $6.20 \pm 0.08^{a}$ & $8.08 \pm 0.50$ & $8.51 \pm 0.17$ \\
\hline & FUCO1 & $7.94 \pm 0.01^{\mathrm{a}}$ & $7.58 \pm 0.04^{a}$ & $6.99 \pm 0.07$ & $4.54 \pm 0.06^{c}$ & $8.75 \pm 0.13$ & $8.46 \pm 0.12$ \\
\hline & FUCO2 & $7.45 \pm 0.05^{b}$ & $6.34 \pm 0.01^{c}$ & $7.05 \pm 0.05$ & $5.53 \pm 0.03^{b}$ & $7.25 \pm 0.26$ & $7.92 \pm 0.20$ \\
\hline & $p$-value & * & $* *$ & ns & $\star *$ & ns & ns \\
\hline
\end{tabular}

All values are given as mean $\pm \mathrm{SEM},(n=10)$. a-d: Means in the same column with different superscripts differ $\left({ }^{*}: p<0.05\right),\left({ }^{* *}: p<0.01\right)$. ns: not significant $(p>0.05)$.

CONT, basal diet; FUCO1, basal diet+100 mg/kg diet of Fucoxanthin; FUCO2, basal diet+200 mg/kg diet of Fucoxanthin. TMAB; total mesophilic aerobic bacteria, TPAB; total psychrotrophic aerobic bacteria.

spp. counts in the breast meat were significantly lower on days 5 and 6 of storage in groups FUCO1 andFUCO2 $(p<0.01)$ relative to the CONT group (Table 5$)$.

Drumstick the values of meat color parameters $L^{*}$ and $a^{*}$ were not affected by fucoxanthin, whereas the $b^{*}$ value significantly increased on the $1^{\text {st }}$ day of storage in only group FUCO1 $(p<0.01)$ relative to the other groups (Table 6). Fucoxanthin supplementation had no effect on the $\mathrm{pH}$ value of the drumstick meat. However, it significantly increased $a_{w}$ on the $5^{\text {th }}$ day of storage only in group FUCO2 $(p<0.05)$ (Table 6). Furthermore, fucoxanthin had no effect on the $\mathrm{pH}$, $a_{w}$ and $a^{*}$ values of the breast meat, but caused $a$ significant increase in the $L^{*}$ value on the $3^{\text {rd }}$ day of storage in group FUCO1, and in the $b^{*}$ value on the $2^{\text {nd }}$ and $5^{\text {th }}$ days of storage in both groups FUCO1 and FUCO2 $(p<0.05)$ relative to the CONT group (Table 7$)$.

\section{DISCUSSION}

Due to the adverse effects of synthetic antioxidants on organisms, the search for alternative natural antioxidants have been researched. Studies have shown that fucoxanthin, which is found in marine brown algae, is a natural and safe antioxidant substance that leaves no residues (Yan et al., 1999).

Similar to other carotenoid-containing substances, due to its hydrophobic structure, fucoxanthin is hydrolyzed into fucoxanthinol by digestive enzymes in the gastrointestinal tract, and is absorbed by intestinal cells (Beppu et al., 2009; Sugawara et al., 2002). In the present study, fucoxanthin supplementation to feeds had no effect on BW (except for days 10 and 17), BWG (except for days 3-10 and 11-17), FI, and FCR of broiler chicks (Table 2). The results obtained in the present study are in agreement with a previous studies that showed that fucoxanthin $(10 \mathrm{mg} /$ day/animal) (Sasaki et al., 2010), marigold extract containing varying levels of several carotenoid types(added at percentages of $0.075 \%, 0.15 \%, 0.30 \%$ and $0.60 \%$ to the feed ration) (Wang et al., 2017), and astaxanthin-rich yeast (Phaffiarhodozyma) (added at concentrations of 10 and $20 \mathrm{mg} / \mathrm{kg}$ to the feed ration) did not affect BWG, FI and FCR of broiler chickens (Perenlei et al., 2014).

Antioxidants significantly reduce lipid peroxidation (Halıcı et al., 2012). Due to its allenic bonds, epoxide and hydroxyl groups, fucoxanthin has a specific 
Table 6 - Effects of dietary fucoxanthin supplementation and storage period on colour parameters, water holding capacity and $\mathrm{pH}$ in chicken breast meat

\begin{tabular}{|c|c|c|c|c|c|c|}
\hline Days & Groups & $\mathrm{L}^{*}$ & $a^{*}$ & $b^{*}$ & WHC & $\mathrm{pH}$ \\
\hline \multirow[t]{4}{*}{1} & CONT & $52.07 \pm 1.68$ & $5.14 \pm 0.59$ & $6.32 \pm 0.15$ & $0.988 \pm 0.001$ & $5.81 \pm 0.01$ \\
\hline & FUCO1 & $56.52 \pm 3.87$ & $4.03 \pm 0.47$ & $7.96 \pm 1.16$ & $0.989 \pm 0.001$ & $5.97 \pm 0.08$ \\
\hline & FUCO2 & $54.37 \pm 3.69$ & $4.81 \pm 0.70$ & $10.25 \pm 1.52$ & $0.989 \pm 0.002$ & $5.81 \pm 0.08$ \\
\hline & $p$-value & ns & ns & ns & ns & ns \\
\hline \multirow[t]{4}{*}{2} & CONT & $49.49 \pm 1.15$ & $5.00 \pm 0.89$ & $6.79 \pm 0.48^{b}$ & $0.987 \pm 0.001$ & $5.95 \pm 0.13$ \\
\hline & FUCO1 & $51.45 \pm 1.06$ & $3.27 \pm 0.49$ & $8.63 \pm 0.33^{a}$ & $0.988 \pm 0.001$ & $5.83 \pm 0.11$ \\
\hline & FUCO2 & $51.53 \pm 0.52$ & $3.59 \pm 0.29$ & $9.44 \pm 0.55^{a}$ & $0.988 \pm 0.001$ & $5.86 \pm 0.01$ \\
\hline & $p$-value & ns & ns & $\star *$ & ns & ns \\
\hline \multirow[t]{4}{*}{3} & CONT & $51.21 \pm 1.49^{b}$ & $3.82 \pm 0.55$ & $8.49 \pm 0.32$ & $0.986 \pm 0.001$ & $5.82 \pm 0.06$ \\
\hline & FUCO1 & $56.08 \pm 0.34^{a}$ & $2.41 \pm 0.57$ & $8.64 \pm 1.61$ & $0.983 \pm 0.001$ & $5.65 \pm 0.05$ \\
\hline & FUCO2 & $49.33 \pm 0.70^{b}$ & $3.32 \pm 0.36$ & $8.62 \pm 0.69$ & $0.985 \pm 0.002$ & $6.00 \pm 0.08$ \\
\hline & $p$-value & $\star \star$ & ns & ns & ns & ns \\
\hline \multirow[t]{4}{*}{4} & CONT & $51.00 \pm 1.63$ & $3.71 \pm 1.01$ & $6.97 \pm 1.36$ & $0.986 \pm 0.000$ & $5.83 \pm 0.06$ \\
\hline & FUCO1 & $53.18 \pm 1.45$ & $2.41 \pm 0.49$ & $7.46 \pm 1.35$ & $0.989 \pm 0.000$ & $5.75 \pm 0.13$ \\
\hline & FUCO2 & $51.50 \pm 1.38$ & $3.66 \pm 0.16$ & $10.14 \pm 0.82$ & $0.987 \pm 0.001$ & $5.86 \pm 0.01$ \\
\hline & $p$-value & ns & ns & ns & ns & ns \\
\hline \multirow[t]{4}{*}{5} & CONT & $51.33 \pm 0.98$ & $3.30 \pm 0.40$ & $6.06 \pm 1.21^{b}$ & $0.987 \pm 0.002$ & $5.90 \pm 0.05$ \\
\hline & FUCO1 & $52.39 \pm 1.14$ & $4.22 \pm 1.56$ & $9.16 \pm 0.59^{a}$ & $0.992 \pm 0.010$ & $5.96 \pm 0.09$ \\
\hline & FUCO2 & $51.47 \pm 0.95$ & $2.86 \pm 0.30$ & $10.09 \pm 0.58^{a}$ & $0.992 \pm 0.006$ & $5.84 \pm 0.04$ \\
\hline & $p$-value & ns & ns & * & ns & ns \\
\hline \multirow[t]{4}{*}{6} & CONT & $56.30 \pm 2.45$ & $3.46 \pm 0.93$ & $10.04 \pm 0.74$ & $0.987 \pm 0.003$ & $6.07 \pm 0.16$ \\
\hline & FUCO1 & $50.82 \pm 0.91$ & $5.28 \pm 0.35$ & $11.48 \pm 0.66$ & $0.989 \pm 0.002$ & $5.93 \pm 0.01$ \\
\hline & FUCO2 & $50.77 \pm 2.00$ & $4.83 \pm 0.50$ & $10.00 \pm 0.11$ & $0.990 \pm 0.001$ & $5.83 \pm 0.12$ \\
\hline & $p$-value & ns & ns & ns & ns & ns \\
\hline
\end{tabular}

All values are given as mean $\pm \mathrm{SEM},(\mathrm{n}=10)$. a-d: Means in the same column with different superscripts differ $\left({ }^{*}: p<0.05\right),\left({ }^{* *}: p<0.01\right)$. ns: not significant $(p>0.05)$.

CONT, basal diet; FUCO1, basal diet+100 mg/kg diet of Fucoxanthin; FUCO2, basal diet+200 mg/kg diet of Fucoxanthin. $L^{*}$ : lightness, $a^{*}$ : redness, $b^{*}$ : yellowness. WHC: water holding capacity

chemical structure and has potential antioxidant activity (Sangeetha et al., 2008). In the present study, fucoxanthin significantly improved CAT and SOD activities and the GSH levels in the liver, breast and drumstick tissues. Furthermore, fucoxanthin significantly decreased MDA levels in all three tissues. These results are consistent with a previous study in rats, where dietary fucoxanthin inclusion increased plasma and liver CAT and SOD activities (Sangeetha et al., 2008). In another study conducted by Wang et al. (2017) in broiler chickens, the addition of lutein and zeaxanthin-containing marigold extract to the feed at a concentration of $0.60 \%$ not only significantly increased SOD activity and GSH levels in the liver and SOD activity in the thigh meat, but also decreased MDA levels in these two tissues. Furthermore, Sasaki et al. (2010) reported that a daily dose of $10 \mathrm{mg}$ of fucoxanthin per bird significantly decreased the plasma concentrations of thiobarbituric acid-reactive substances (TBARS) in broiler chickens. Amarked effect of fucoxanthin on antioxidant metabolism was observed in the present study not only in the liver tissue, characterized by a high level of metabolic activity, but also in the metabolism of the breast and drumstick tissues.
Microbial count is a significant criterion that defines the quality of meat. While some microorganisms are naturally found in meat, most contaminate meat during processing. It is known that the number of microorganisms in meat increases as storage time is extended (Imik et al., 2012b). In the present study, it was determined that fucoxanthin significantly reduced the Staphylococcus spp. and TMAB counts in the breast and drumstick meat on the $5^{\text {th }}$ and $6^{\text {th }}$ days of storage. It was observed that the effects of fucoxanthin on bacteria were variable and limited (Tables 4 and 5). Although a previous study reported that marine algae have antimicrobial effects (Cox et al., 2014), to the authors' knowledge, this is the only study on the antimicrobial effect of fucoxanthin on meat. In view of the available literature reports and based on the results obtained in the present study, it is suggested that both the growth and increase in number of the microorganisms found in the initial flora of meat during the storage period can be limited to a certain extent by the use of natural additives (Bórnez et al., 2009; Imik et al., 2012b).

Meat color has a strong influence on consumer preference. The globin, porphyrin ring and iron ion in 
Table 7 - Effects of dietary fucoxanthin supplementation and storage period on colour parameters, water holding capacity and $\mathrm{pH}$ in chicken drumstick meat.

\begin{tabular}{|c|c|c|c|c|c|c|}
\hline Days & Groups & $L^{*}$ & $a^{*}$ & $b^{*}$ & WHC & $\mathrm{pH}$ \\
\hline \multirow[t]{4}{*}{1} & CONT & $51.00 \pm 2.85$ & $6.51 \pm 0.25$ & $6.51 \pm 0.61^{b}$ & $0.987 \pm 0.002$ & $6.11 \pm 0.10$ \\
\hline & FUCO1 & $58.90 \pm 5.00$ & $6.49 \pm 1.29$ & $11.77 \pm 0.95^{\mathrm{a}}$ & $0.992 \pm 0.001$ & $6.05 \pm 0.05$ \\
\hline & FUCO2 & $47.98 \pm 1.62$ & $6.84 \pm 1.08$ & $8.43 \pm 0.89^{b}$ & $0.986 \pm 0.004$ & $6.27 \pm 0.01$ \\
\hline & $p$-value & ns & ns & ** & ns & ns \\
\hline \multirow[t]{4}{*}{2} & CONT & $54.73 \pm 3.99$ & $6.98 \pm 0.40$ & $6.89 \pm 0.83^{\mathrm{ab}}$ & $0.992 \pm 0.002$ & $6.03 \pm 0.00$ \\
\hline & FUCO1 & $50.01 \pm 2.05$ & $6.76 \pm 0.71$ & $4.71 \pm 1.18^{b}$ & $0.991 \pm 0.001$ & $6.36 \pm 0.16$ \\
\hline & FUCO2 & $49.52 \pm 0.61$ & $7.04 \pm 0.73$ & $8.65 \pm 0.53^{\mathrm{a}}$ & $0.989 \pm 0.000$ & $6.17 \pm 0.01$ \\
\hline & $p$-value & ns & ns & * & ns & ns \\
\hline \multirow[t]{4}{*}{3} & CONT & $56.09 \pm 0.20$ & $5.66 \pm 0.50$ & $6.33 \pm 2.66$ & $0.989 \pm 0.002$ & $6.11 \pm 0.20$ \\
\hline & FUCO1 & $52.04 \pm 1.93$ & $6.76 \pm 1.11$ & $6.85 \pm 1.43$ & $0.985 \pm 0.002$ & $6.12 \pm 0.10$ \\
\hline & FUCO2 & $48.70 \pm 1.25$ & $8.35 \pm 0.94$ & $9.30 \pm 0.68$ & $0.988 \pm 0.001$ & $6.35 \pm 0.01$ \\
\hline & $p$-value & ns & ns & ns & ns & ns \\
\hline \multirow[t]{4}{*}{4} & CONT & $50.06 \pm 1.87$ & $6.98 \pm 1.17$ & $6.93 \pm 1.37$ & $0.989 \pm 0.000$ & $6.21 \pm 0.13$ \\
\hline & FUCO1 & $49.67 \pm 2.35$ & $8.16 \pm 1.88$ & $9.64 \pm 0.78$ & $0.990 \pm 0.000$ & $6.23 \pm 0.08$ \\
\hline & FUCO2 & $47.39 \pm 1.00$ & $6.62 \pm 0.26$ & $7.54 \pm 1.24$ & $0.991 \pm 0.000$ & $6.25 \pm 0.04$ \\
\hline & $p$-value & ns & ns & ns & ns & ns \\
\hline \multirow[t]{4}{*}{5} & CONT & $51.16 \pm 1.85$ & $6.74 \pm 0.70$ & $6.34 \pm 0.94$ & $0.987 \pm 0.001_{b}$ & $6.43 \pm 0.36$ \\
\hline & FUCO1 & $53.43 \pm 0.73$ & $7.06 \pm 0.63$ & $10.49 \pm 1.75$ & $0.987 \pm 0.001^{b}$ & $6.10 \pm 0.13$ \\
\hline & FUCO2 & $51.51 \pm 0.88$ & $6.71 \pm 0.81$ & $9.92 \pm 0.55$ & $0.995 \pm 0.000^{a}$ & $6.37 \pm 0.06$ \\
\hline & $p$-value & ns & ns & ns & * & ns \\
\hline \multirow[t]{4}{*}{6} & CONT & $50.89 \pm 1.41$ & $7.77 \pm 0.79$ & $5.04 \pm 0.63$ & $0.994 \pm 0.003$ & $6.26 \pm 0.22$ \\
\hline & FUCO1 & $52.13 \pm 1.42$ & $4.89 \pm 1.11$ & $8.66 \pm 1.82$ & $0.992 \pm 0.001$ & $6.56 \pm 0.21$ \\
\hline & FUCO2 & $49.46 \pm 0.86$ & $5.31 \pm 0.82$ & $9.24 \pm 0.57$ & $0.990 \pm 0.000$ & $6.31 \pm 0.01$ \\
\hline & $p$-value & ns & ns & ns & ns & ns \\
\hline
\end{tabular}

All values are given as mean $\pm \mathrm{SEM},(\mathrm{n}=10)$. a-d: Means in the same column with different superscripts differ $\left({ }^{*}: p<0.05\right),\left({ }^{* *}: p<0.01\right)$. ns: not significant $(p>0.05)$.

CONT, basal diet; FUCO1, basal diet+100 mg/kg diet of Fucoxanthin; FUCO2, basal diet+200 mg/kg diet of Fucoxanthin. $L^{*}$ : lightness, $a^{*}$ : redness, $b^{*}$ : yellowness. WHC: water holding capacity

the myoglobin and hemoglobin pigments, which give meat its specific color, are known to be very sensitive to oxidation (Barbut, 2016; Mancini \& Hunt, 2005). Lipid peroxidation during storage not only adversely affects meat quality (color and taste), but also constitutes a health risk in the event of the consumption of meat that has undergone lipid peroxidation (Esterbauer et al., 1991; Rhee, 1988). In the present study, it was determined that although fucoxanthin supplementation had no effect on the $L^{*}$ and $a^{*}$ values (color parameters) of the breast and drumstick meat, it significantly reduced the adverse effects of storage on the $b$ *value (Tables 6 , 7). Sasaki et al. (2010) reported that a daily oral dose of $10 \mathrm{mg}$ of fucoxanthin administered to broiler chickens did not affect either meat TBARS concentration or $L^{*}$ and $a^{*}$ values, but significantly increased $b^{*}$ value. It has also been reported that the addition of $200 \mathrm{mg} / \mathrm{kg}$ of fucoxanthin to chicken breast meat, before or after cooking, increased $a^{*}$ and $b^{*}$ values and decreased the $L^{*}$ value on 1 and 6 days of storage when the meat was stored at $+4^{\circ} \mathrm{C}$ (Sasaki et al., 2008). Furthermore, it has been determined that, while the addition of marigold extract to broiler feed at percentages of $0.075 \%, 0.15 \%, 0.30 \%$ and $0.60 \%$ did not affect the $L^{*}$ value, the $a^{*}$ value was increased only by the addition of $0.60 \%$ of marigold extract, and the $b$ * value was increased by the addition of $0.15 \%, 0.30 \%$ and $0.60 \%$ of marigold extract (Wang et al., 2017). In a study with broiler chickens, Perenlei et al. (2014) determined that the addition of astaxanthin-rich yeast (Phaffiarhodozyma) to the feed at concentrations of 10 and $20 \mathrm{mg} / \mathrm{kg}$ did not have any effect on the $L^{*}$ value of breast meat at Oand $48 \mathrm{~h}$, but its supplementation at a concentration of $20 \mathrm{mg} / \mathrm{kg}$ significantly increased both $a^{*}$ and $b *$ values.

Meat water activity describes the ability of muscle tissue to retain moisture and directly influences meat palatability in terms of taste, tenderness and juiciness. The maintenance of meat $a_{w}$ at a minimal level is a major influence on post-mortem metabolism and meat quality (Isengard, 2001; Zhou et al., 2010). In the present study, fucoxanthin had no effect on the $a_{w}$ of the breast or drumstick meat (Tables 6 and 7). To the authors' knowledge, there are no reports to date on the effect of fucoxanthin on the $a_{w}$ of meat. On the other hand, marigold extract, which contains lutein and zeaxanthin of the various carotenoid types, has been reported to decrease chicken meat water holding 
capacity (Wang et al., 2017), where as astaxanthin-rich yeast (Phaffiarhodozyma) has not shown such effect (Perenlei et al., 2014).

The conversion of muscle glycogen into lactic acid and the reduction of meat $\mathrm{pH}$ value both play an important role in the post-mortem metabolism of meat. In the present study, fucoxanthin did not affect the $\mathrm{pH}$ values of the breast or drumstick meat of broiler chickens (on 1, 2, 3, 4, 5 and 6 days of storage) (Tables $6,7)$. These results are consistent with the study of Perenlei et al. (2014), who supplemented a broiler feed with 10 and $20 \mathrm{mg} / \mathrm{kg}$ of astaxanthin-rich yeast (Phaffiarhodozyma) and did not observe any effect on the $\mathrm{pH}$ value of the breast meat at 0 and $48 \mathrm{~h}$ postslaughter. Furthermore, Wang et al.(2017)reported that marigold extract had no effect on the $\mathrm{pH}$ value of chicken thigh meat at $45 \mathrm{~min}$ and $24 \mathrm{~h}$ post-slaughter.

\section{CONCLUSION}

The results of the present study show that the dietary addition of fucoxanthin did not affect the growth performance of broilers. However, it reduced Staphylococcus spp. counts in the meat obtained and had variable effects on other microorganisms in meat. The effects of fucoxanthin on meat color parameters were also variable. In addition, fucoxanthin dietary supplementation enhanced CAT and SOD activities in the liver, breast and drumstick tissues, and the reduction of lipid peroxidation levels demonstrated that fucoxanthin is a natural antioxidant capable of regulating the antioxidant metabolism of chicken meat.

\section{REFERENCES}

Alimentarius C. Codex alimentarius commission. Rome: Fao; 2010. Available from: http://www.codexalimentarius.net/gsfaonline/additives/index. html.

AOAC - Association of Official Analytical Chemists. Official methods of analysis of AOAC international. 15th ed. Arlington; 2005.

Barbut S. Poultry products processing: $\mathrm{n}$ industry guide. Boca Raton: CRC Press; 2016.

Baumgart J, Firnhaber J ,Spcher G. Mikrobiologischeuntersuchung von lebensmitteln. Hamburg: Behr's Verlag; 1993.

Beppu F, Niwano $Y$, Sato E, Kohno M, Tsukui T, Hosokawa M, et al. In vitro and in vivo evaluation of mutagenicity of fucoxanthin (FX) and its metabolite fucoxanthinol $(\mathrm{FXOH})$. The Journal of Toxicological Sciences 2009; 34(6):693-698.

Bórnez $\mathrm{R}$, Linares MB, Vergara $\mathrm{H}$. Microbial quality and lipid oxidation of Manchega breed suckling lamb meat: Effect of stunning method and modified atmosphere packaging. Meat Science 2009;83(3):383-389.

Cox S, Turley GH, Rajauria G, Abu-Ghannam N, Jaiswal AK. Antioxidant potential and antimicrobial efficacy of seaweed (Himanthalia elongata) extract in model food systems. Journal of applied phycology 2014;26(4):1823-1831.

Esterbauer H, Schaur RJ, Zollner H. Chemistry and biochemistry of 4-hydroxynonenal, malonaldehyde and related aldehydes. Free Radical Biology and Medicine 1991;11(1):81-128.

Fang $Y Z$, Yang $S$, Wu G. Free radicals, antioxidants, and nutrition. Nutrition 2002;18(10):872-879.

Gökalp HY, Kaya M, Tülek Y, Zorba O. Guide for quality control and laboratory application of meat products [Publ 751]. $4^{\text {th }}$ ed. Erzurum: Atatürk University; 2001.

Gumus R, Ercan N, Imik H. The effect of thyme essential oil (thymus vulgaris) added to quail diets on performance, some blood parameters, and the antioxidative metabolism of the serum and liver tissues. Revista Brasileira de Ciência Avícola 2017;19(2):297-304.

Gümüş $R$, Imik $H$. The effect of Yucca schidigera powder added to lamb feed on fattening performance, some blood parameters, the immune system, and the antioxidative metabolism of the hepatic tissue. Turkish Journal of Veterinary and Animal Sciences 2016;40(3):263-270.

Halıcı M, Imik H, Koç M, Gümüş R. Effects of $\alpha$-lipoic acid, vitamins E and $\mathrm{C}$ upon the heat stress in Japanese quails. Journal of Animal Physiology and Animal Nutrition 2012;96(3):408-415.

Heo SJ, Yoon WJ, Kim KN, Ahn GN, Kang SM, Kang DH, et al. Evaluation of anti-inflammatory effect of fucoxanthin isolated from brown algae in lipopolysaccharide-stimulated RAW 264.7 macrophages. Food and Chemical Toxicology 2010;48(8):2045-2051.

Hosakawa M, Bhaskar N, Sashima T, Miyashita K. Fucoxanthin as a bioactive and nutritionally beneficial marine carotenoid: A review. Carotenoid Science 2006;10:15-28.

Imik H, Atasever MA, Urcar S, Ozlu H, Gumus R, Atasever M. Meat quality of heat stress exposed broilers and effect of protein and vitamin E. British Poultry Science 2012a;53(5):689-698.

Imik H, Ozlu H, Gumus R, Atasever MA, Urcar S, Atasever M. Effects of ascorbic acid and $\alpha$-lipoic acid on performance and meat quality of broilers subjected to heat stress. British Poultry Science 2012b;53(6):800-808.

Isengard HD. Water content, one of the most important properties of food. Food Control 2001;12(7):395-400.

Kotake-Nara E, Asai A, Nagao A. Neoxanthin and fucoxanthin induce apoptosis in PC-3 human prostate cancer cells. Cancer Letters 2005;220(1):75-84.

Mancini RA, Hunt M. Current research in meat color. Meat Science 2005;71(1):100-121.

Matsuno T. Aquatic animal carotenoids. Fisheries Science 2001;67(5):771783.

NRC - National Research Council. Nutrient requirements of poultry. $9^{\text {th }}$ ed. Washington: National Academy Press; 1994.

Perenlei G, Tojo H, Okada T, Kubota M, Kadowaki M, Fujimura S. Effect of dietary astaxanthin rich yeast, Phaffia rhodozyma, on meat quality of broiler chickens. Animal Science Journal 2014;85(10):895-903.

Rhee KS. Enzymic and nonenzymic catalysis of lipid oxidation in muscle foods. Food Technology 1988;42(6):127-132.

Sangeetha RK, Bhaskar N, Baskaran V. Fucoxanthin restrains oxidative stress induced by retinol deficiency through modulation of $\mathrm{Na}+\mathrm{Ka}+-\mathrm{ATPase}$ and antioxidant enzyme activities in rats. European Journal of Nutrition 2008;47:432-441 
Sasaki K, Ishihara K, Oyamada C, Sato A, Fukushi A, ArakaneT, et al. Effects of fucoxanthin addition to ground chicken breast meat on lipid and colour stability during chilled storage, before and after cooking. AsianAustralasian Journal of Animal Sciences 2008;21(7):1067-1072.

Sasaki K, Ishihara K, Yamazaki M, Nakashima K, Abe H, Oyamada C, et al. Oral administration of fucoxanthin increases plasma fucoxanthinol concentration and antioxidative ability and improves meat color in broiler chicks. The Journal of Poultry Science 2010;47(4):316-320.

SPSS. Statistical packages for the social sciences. 20 2 th ed. Chicago: IBM; 2011.

Sugawara T, Baskaran V, Tsuzuki W, Nagao A. Brown algae fucoxanthin is hydrolyzed to fucoxanthinol during absorption by Caco-2 human intestinal cells and mice. The Journal of Nutrition 2002;132(5):946951.
Surai P. Antioxidant systems in poultry biology: superoxide dismutase. Journal of Animal Research and Nutrition 2015;1(1).

Wang S, Zhang L, Li J, Cong J, Gao F, Zhou G. Effects of dietary marigold extract supplementation on growth performance, pigmentation, antioxidant capacity and meat quality in broiler chickens. AsianAustralasian Journal of Animal Sciences 2017;30(1):71.

Yan X, Chuda Y, Suzuki M, Nagata T. Fucoxanthin as the major antioxidant in Hijikia fusiformis, a common edible seaweed. Bioscience Biotechnology and Biochemistry 1999;63(3):605-607.

Zhou GH, Xu XL, Liu Y. Preservation technologies for fresh meat-A review. Meat Science 2010;86(1):119-128. 